\title{
メタリコンこ防 蝕法
}

曾員 理學婹士 加 瀨 勉

目次

\author{
I. 綪 \\ 言 \\ II. 噴射器械 (ヒストル) \\ III. 嘖射 $の$ 理論 \\ IV. 噴射した金雷の多孔性

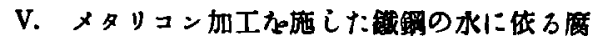
触

\section{I. 粕}

鐵其の他の廉價な金屬或は銹易い金屬の表 面に他の金屬特に贵金屬或は防銹性她附與す る金屬灻被㽝させる方法，郎古一般に云へば 鍍金法には色々ある。（1）電氣鍍金は金屬㹂 の溶液と電流とに传る方法で，陰極に被鍍金 物，陽極に鍍金に要する金屬声吊し，適當の 電流名䢎すれば宜しい（2）ブリキやトタン 板を造る場合の樣に路融金屬中に被鍍金物を 紫時浸请して目的名達することも出來る。(3) 被鍍金物在鋮金用の金屬の粉末を以て包み， 嘘中に於て適常の溫度に適當の時間げけ加熱 すれば摭散が起り，被鍍金物に對して鍍金首 としての合金の表面を與へる.之を金屬七”

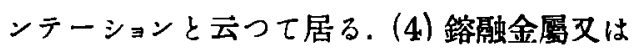

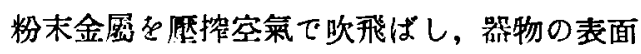
に附着させる方法はメタリコン (metallikon 或は metal spraying) でる。.之に使用す る機㭜をピストル(pistol）と云つて居る。其 の結果は酸化物が多く, 又機械的附着で往々
VI. メタリコン加工か施とたフフルミウムの水 に依乃席蝕

VII. メタリコン加工か施したマダネシウムの水 に依乃原蝕

VIII. 結 論

剝離し易いすのもあるが，近來の作業に於て はかなり旨くなり，良結果を與へて居るすの 当ある.殊に此の方法に於ては被鍍金物は何 でう宜しく，鍍金用の金屬す大抵のものは出 來るから新しい工業として重要性をすつて居 る.

ノメタリコン或は噴射法は機械の磨耗部を修 繥する爲にも用ひられるが，防蝕が最す重要 な用途であらう。不銹鋼の如きは特别な埸合 の外は值段の高い點で一般に都合が㤮いか ら，メタリコンを賞用すべき場合が隨分多か らうと思ふ。

メタリコンを行ふには先づサンドフラス チング (sand blasting), 郎ち砂吹附けを行 ひ,次に金屬を吹附ける(第 1 圖及び第 2 圆案 照)。亞鉛やアルミニゥムを吹附けたすのは 空载中に出して置いて最す良い防蝕膜率人 る.倘其の上にへイントを症附すれば、ヘイ ントも落ち附いて一展有效に働く. 
第 1 圖

サンドブラスチング 作業系況

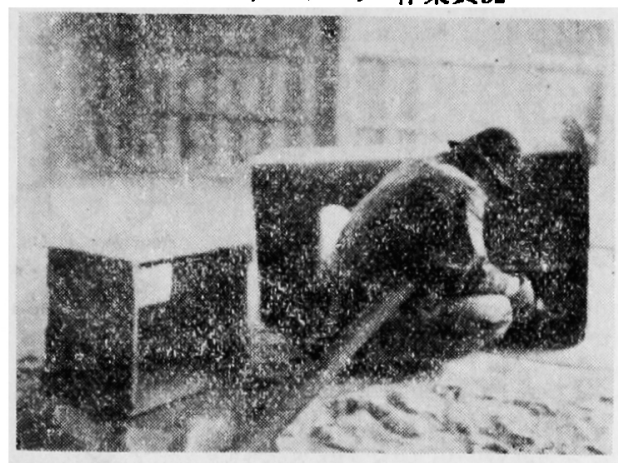

メタリュンはトイッ及びフランスを始めと し近來アメリカ等です部盛に行はれて居る が,日本では筆者か屡、本誌にす記述した如く 江澤氏が之を軨入し，工業化するに至つて以 來，各方面で之が嘪施を企てて居る．筆者は 早い頃汃ら漞しく各地のメタリコン工場に出 入し，其の喷射の實況を注意し，且加工品に
第 2 圆

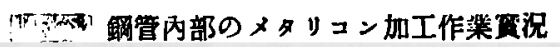

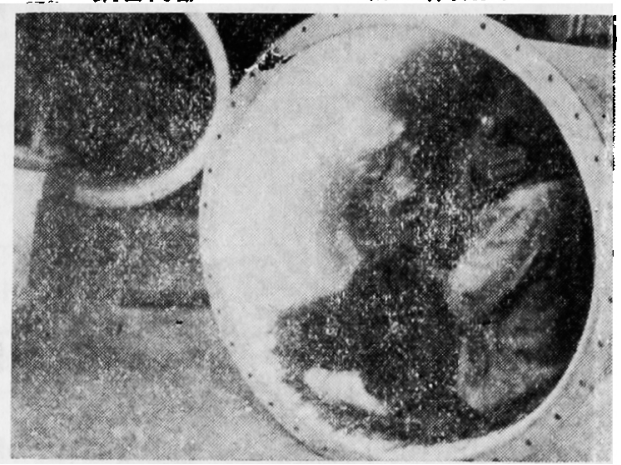

就いて種々の實驗を行ひ，本誌にも數回をれ か報告をもたらしたことがある。(1)

次に記述する事項（第 II 〜III 章）はメタリ コンに關する䡚近の文獻を引用し，之に筆者 の其の後の筫駿結果 (第 $\mathrm{V}$ 章以下) を加筆し たものである.

\section{II. 噴射器埛（ピストル）}

現今歌米を通して噴射法には大體三つの方 法がある.概要る記述すれば次の通りである。

(1) ワイヤビストル(Wire-Typé Pistol)

此の式のものは色々出て居るけれどす大同 小異である。ビストルは小さい宾氣タービン より成り，每分 30 50,000 超轉し、齿車に伡 つて，ワイヤを押へてるロールを動かし，鎔 融筒口に揆る樣にしてある，医搾石炭瓦斯或 はフセチレンと酸素とは焰に供給され，壓搾 空氣は鎔融金屬を噴第化するに用ひられる (一例として第3 圖突照).

ワイヤは太くしょうと企てられて居るか， 米國のピストルは徑 $1 / 8$ in (3.2 mm), 英國の
それは徑 $2 \mathrm{~mm}$ のものを用ひ得る。筒口は 英·佛・米國等に依つて多少異なる所がある。 近頃は刃大きい面に一樣に吹附ける第に，送 風器を附けたるのるおる。

（2）路融金或ピストル(Molten Metal Pistol) 1924～1926 年間に Amsterdam の C. J. Jung 及び H.J. Versteegに依つて發明され た型から改良されだのでる。

鎔融金屬が容器から重力に依つてビストル へ供給される.而して容器の溫度は下方にあ るブンゼン焰で保持される樣になつて居る (第4 圆罂). 此の方法は今の所主として亞 鉛の噴射に利用される。

（1）加漟，本誌，3 (1927), 251；12 (1936), 483. 
第 3 圖 英國式 ワイヤビストル

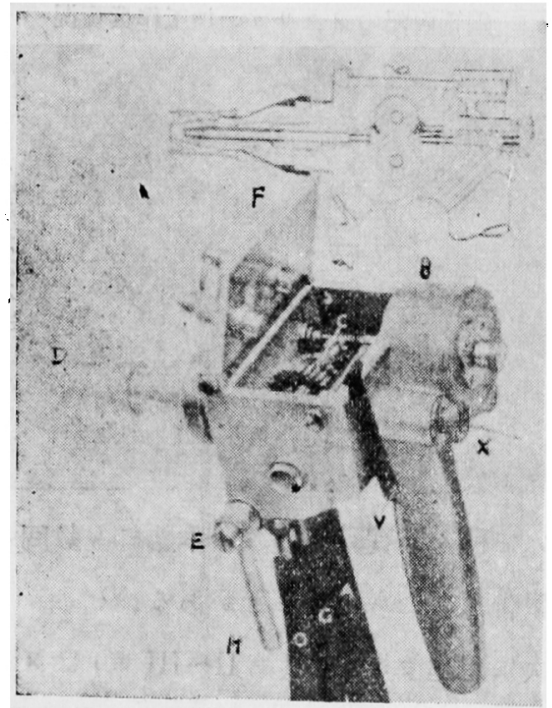

$A$ 造風管, $B$ タービン室. $C$ 蝶番腕金, $D$ ヒ ストル筒口, $E$ 瓦斯調節瓣, $F$ 蝶番蓋, $G$ 败 料瓦斯管, $H$ 都把手, $O$ 酸素送入管, $V$ 骤條

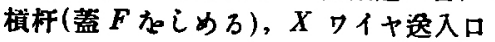

第 4 圖鎔融金忽ビストル

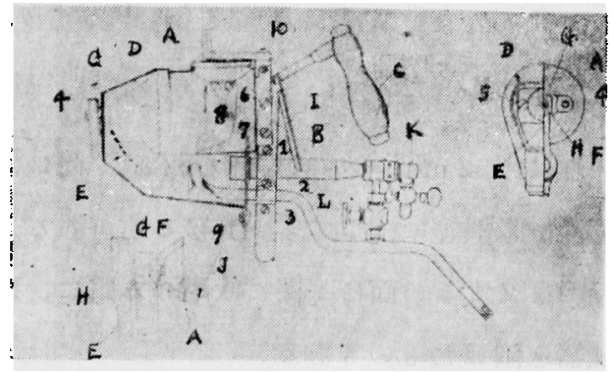

$A$ 容器, $B$ 橙口, $C$ 把手, $D$ 賲風器, $E$ 前板, $F$ 医摧空氣, $G$ 送氣器, $H$ シルバースチール 筒口, $I$ 謨手板, $J$ 楯， $K$ 空氣及び瓦斯の買射 器, $L$ 空氣調節器

（3）粉末法ビストル(Powder Process Pistol)

粉末法のピストルとしては英國の特許にな つて居る Schori の發明したすのだけが賽用 的である. 粉末か酸素一瓦斯焰を通して吸込 まれ，目的物に吹附けられる(第 5 圖空照)。 㲔 $V$ に低り壓搾空氣か～$G$ 室に入る。此處て 分れて一部は $A$ 室を敕て筒口 $B$ に至る. 此 の際 $E$ 管中に部分的真空を生する，是に依つ
第 5 圖 Shori ピストル及び㸮末容器

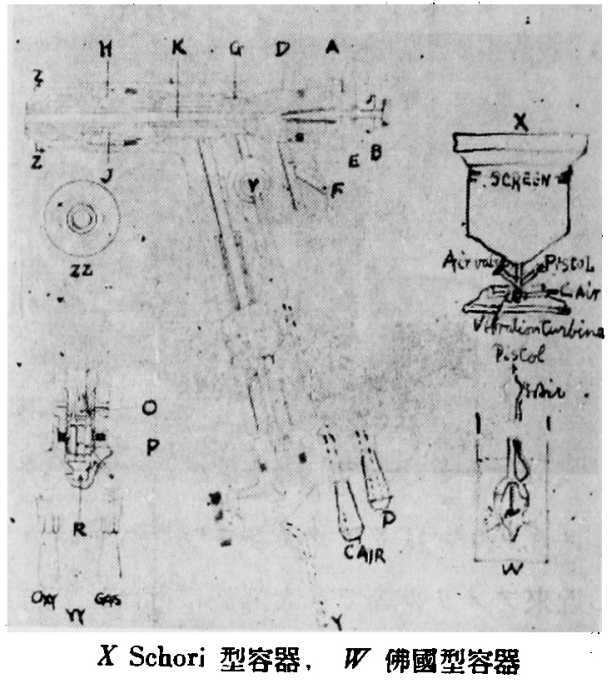

て粉末を供給し，且 $\boldsymbol{F}$ に於て大氣と連なる。 Fは拇指で抑へたり離したりして粉末の吸收 及び抑制を行ふ，金屓枌末は放射狀の孔 $D$ を通過し， $K$ 管に入る.宾氣は $G$ 室から $H$ 孔に拔け， $Z Z$ で示された棈圆形の宾間に出 る. 此處て圓形の焰を圍み，鎔融粒子を器物 克噴射する，把手の下方の $P$ 满からでチ レンが入る.酸素は $R$ 孔から中央の $O$ 孔 に入る．混合氣體は $J$ 孔を流れて筒口に至 ク，そこで發火する。

以上 3 種の方法には一長一短がある。それ を表解すれば第 I表に示す通りである。

佾メタリコン用ピストルには同しくくワイヤ に伡るすのでも鎔融に瓦斯を用ひる外電弧を 用ひるるのるある. 本邦では特に此の䉓氣式 のビストルが發澾して居る。何れにすせよ器 物は先づ砂を吹附けて粗面にし，头にピスト ルの筒口真の面に對して約 $30^{\circ}$ に傾けて喷 射するのが宜しい。 


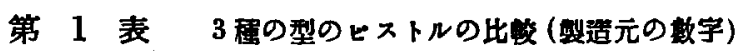

\begin{tabular}{|c|c|c|c|}
\hline$\cdot$ & 英国 $\nabla 1+$ 法 & 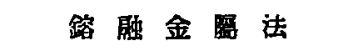 & 末 \\
\hline 跣 & 單紲ブラッグ型ケースス & ブンセン短に湯ロがついた & 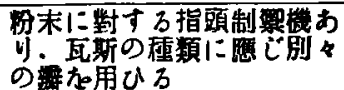 \\
\hline 活 動 部 & 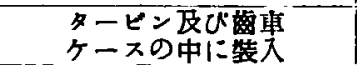 & 無 & $\checkmark$ \\
\hline 量 & $3 \frac{1}{2} \mathrm{lb}$ & $6 \frac{1}{2} \mathrm{lb}$ & $2 \frac{\pi}{4 b}$ \\
\hline 金蝈の形羾 & 经 $1,1 \frac{1}{2}, 2 \mathrm{~mm}$ の線 & 桠中で鎔がた鎔塊 & 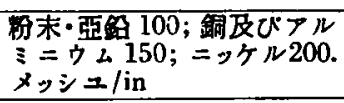 \\
\hline 鉻融點の限界 & $1559^{\circ} \mathrm{C}$ & $600^{\circ} \mathrm{C}(\mathrm{Al}-\mathrm{Si}$ 合金) & $1550^{\circ} \mathrm{C}$ (英國では鎆が最高) \\
\hline 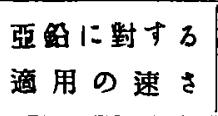 & $\begin{array}{l}5 \mathrm{lb} / \mathrm{hr} ; 17 \mathrm{ft}^{2} / \mathrm{hr}(0.005 \text { in } \\
\text { の厚ざ), } 11.9 \mathrm{lb} / \mathrm{hr} \text {, 㣙 } 2 \\
\mathrm{~mm} \text { の線か用ひる }\end{array}$ & $16 \mathrm{lb} / \mathrm{hr}$, 柽杂用ひる & $20 \mathrm{lb} / \mathrm{hr}$ \\
\hline 耗 & $10 \sim 20 \%$ & $10 \sim 20 \%$ & $20 \sim 30 \%$ \\
\hline 素 & $30 \sim 40 \mathrm{ft}^{\mathrm{s}} / \mathrm{hr}, 25 \mathrm{lb} / \mathrm{in}^{2}$ & 何し用ひない & $50 \mathrm{ft}^{3} / \mathrm{hr}, 14 \sim 28 \mathrm{lb} / \mathrm{in}^{2}$ \\
\hline 然 橈 瓦 斯 & 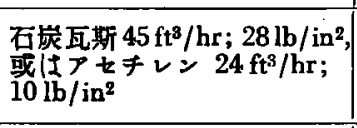 & 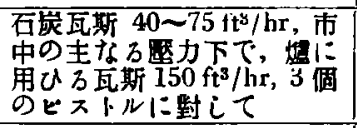 & 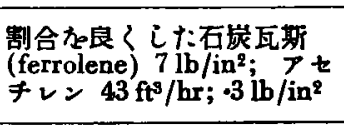 \\
\hline 호 & $15 \mathrm{ft}^{3} / \mathrm{min} ; 45 \mathrm{lb} / \mathrm{in}^{2}$ & $15 \mathrm{ft}^{3} / \min ; 65 \sim 75 \mathrm{lb} / \mathrm{in}^{2}$ & $15 \mathrm{ft}^{3} / \mathrm{min} ; 43 \mathrm{lb} / \mathrm{in}^{2}$ \\
\hline 正规の作業距離 & 3 in & 5 in & $10 \sim 12$ in \\
\hline 內部の出捚 & 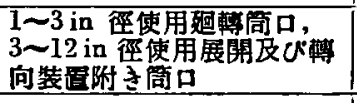 & 浅い任掛けシけ & 浅い任掛 \\
\hline 頭 上 作 業 & 面倒がない & 不可能 & 面锶がはい \\
\hline
\end{tabular}

\section{III. 噴射の理論}

Schoopに依れば原子化した金屬は膨脹す る空氣の突風の泠却效果に基づき飛躍の際に 凝固する．微粒子が器物の表面を衝すると きはそれ等の運動のエネルギーが熱に變し， それが䴇瞬間的に微粒子は可塑性となり，互 に鎔接すると云ふ。けれどす Amold(2) 及び Schenk に依れば所要の熱量を生するに必要 な速さは此の方法で得られる何れの值よりる 過大である，氏の說を支持する第にSchoop は可然性の物質の上に吹附けられることを指 摘し，及金屬氣流の溫度は塞暖計て測定され
た所に依れぱ $60^{\circ} \sim 70^{\circ} \mathrm{C} に$ 過きないことを 示して居る.

併し乍ら Thormann は近頃筒口から 5 in $(12.7 \mathrm{~cm})$ の距墔に於ける喷射した鐵の微粒 子の溫度は $1000^{\circ} \mathrm{C}$ でることを示し，而し てビストルを接近した一個所に差し向けたま まにして居ると，堆積した金屬粒子が揢厰す ることは周知の事實である. Schoop の說に 依れば冷たい粉末る固着する被覆を生成する 稼に噴射し得られることになるか，此の方法 では旨く行かないことが知られて居る。

(2) H. Arnold. Zs. anorg, chem., I (1917), 209. 
Karg, Kutscher 及び Reininger の左祖す

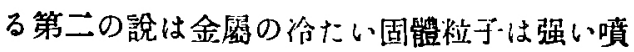
射の壓力に依つて器物の空隙中に打古込まれ ること定假定して居る。

E. C. Rollason の贊する說は噴射㙨械の 如何に依り，微粒子分完全に或は部分的に焰 の中で鎔融し，氣流中を走る閒はかなり徐々 に泠却する，と云ふのは二物澌の遇動の美は 佲どないからであると云ふ。ピストルか器物 に近く（1３in）保持されるとさ仙微粒子か 表面に衙繁する際に未だ触體の形である。故 に落下した鏑の滴の栐な飛ばっ散りを造り
(第6 圖客照)，而して互に抱著することにな る．高度の倍率で是等の飛ばつ散りを檢鏡す れば噴射した薄層を橫切つて圆桂狀の結晶生

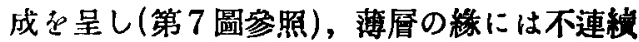
の酸化物被膜や室隙を存して居る。而して是 等の結晶は微粒子が表面を衝戝してから生成 きれたに違ひない，微粒子が表面に堆程した 後は，續いて噴射する氣流に依うて迅速に泠 却され，而して器物は少量の熱を導き去るに 過ざないに拘らす，低鎔融點の金廈を正規に 貲射しても之受ける可燃性の物質が燃燒す るに至らない。

筒口から一層遠い距離にて噴射 すれば徽粒子は凝固點以下に冷却
第 6 圆

硝子に筫射した銅；ワイヤ 法，霹滑寫溟。 $\times 40$

\section{第 7 圆}

佛國ワイヤヒストルに依

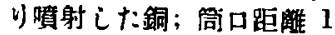

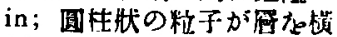
切つて居万.腐触しもたの.

$\times 833$

第 8 阙

英國ビストルで噴射した亞 鉛; 石炭瓦斯使用, 距洞倠 $1 \mathrm{in}$, 遊離した酸化物气氣孔、氣 孔 $1.1 \%$,密距(トルエン中) 6.56 ,

$\times 320$ し，飛ばつ散りを形成しない，然 し運動のエホルギーは十分にある から，微粒子か變形して薄片狀の 詰物となり，細かい小孔を閉塞す るであらう．更に距離を大きくす れば微煜子は著しく多孔質で堆積 した砂狀の集團を構成する．此の 說は本質的に Turner 及び Budgen $^{(3)}$ のそれと一致するるのであ る。

\section{IV. 噴射した金皊の多孔性}

噴射した金屬の密度は常に鋀込 んだ材料よりる小さい，而して此 の事は其の多孔性或は策孔率 (porosity) と酸化物の介在とに依る。 獨立した空陌及び內部で關聯した 氣孔から成る所の多孔性は絕對的

(3) T. H. Turner and N. F. Budgen, "Melal Spraying," (1926). 
に見栍ることが困奞であり，而して文㱆には 何等の數值す見當らない.內部關聯した氣孔 は液體及は氣體をして金虽に渗透させ，これ は應用に當つては不都合を來すものておる。 例人ば崖防止の目的を以て銅メタリコンを 施した場合或は防銹の目的や以て金屬地金よ りる電氣的敛性の（郎ちイオン化傾向の小さ い)金屬を被㪇した場合などはそれである.內 部て連䊧した多孔性(或は唀性)は次の方法 に侬つて算定されて居る．噴射した金属の試 料 (厚さ $1 / 8 \sim 3 / 16$ in 郎 $50.32 \sim 0.48 \mathrm{~cm}$ ) te 造り，地金から引制かし，先う科量した挠。 トルエン中に吊しなが方び科量する，溫度 は $\pm 1{ }^{\circ} \mathrm{C}$ であつた。トルンは迅速江策孔 中に济透し，而してそれから計算した比重は 金屬・酸化物及び拓立した氣孔に依る。さこで 試料河原下に扣熱し，原重量が得られるに 至つて止める(つまりトルエンを驅逐する䉆 である).

次に陚料に極く薄く $(0.02 \sim 0.04 \mathrm{~g}$ 位) ワ七 ソンを凖り附け，而して蒸溜水中に吊して科 量する．脂油の薄膜は水が氣孔中に斏入する の防き，而して適當の值梠與へた。斯椂に して得られた二つの比重の差を氣孔率(\%)に して其の數例を示せば，亞鉛の噴射に就いて 英國ワイヤ法は $1 １ 2 \%$, 鎔融金屬法は 10 17\%，粉末法は 13〜20\% 位の数值孛與へて 居る。トルエン中の密度と同し金屬の箁物の

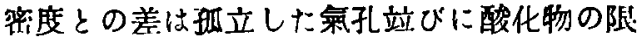
度を示すことになる。此の結果に倩れば粉末 法は最す大きい多孔性の被塏を與人て居る。 而してこれは明らかに粉末溫度か低い丽に 目的物に衝媻しても互に密着し合はないかり である. 英國の石览瓦斯を用ひるワイヤピ ストルは內部て連續した氣孔の少い被覆を 生するけれども，トルエン中の密度は小さい から明らかに獨立した氣孔が相當にあるもの と思はれる。これは哭微鏡組織を調へて見れ ば首肯される所である。多くの場合に於て酸 化物は氣孔を充け方低向がある。

是等の筫驗に於て目的物からの筒口距離の 影響は研究された。筒口距離が非常に小ざけ れば氣孔率は極小である。然し简口距離が增 すに從つて氣孔率か;迅速に增大する。此の結 果は豫期されてたきのである．如何となれば筒 口距雖が近ければ微粒子が十分可塑性で互に 密着し合ふものと思はれるからである．简口 距離か十分大きくなると微粒子は冷たく, 固 く，且速度が心さい，從つて弛やかな堆積狀 の組織灻構成することになる。

不幸にして普通のピストルは其の構造が極 く近距離で賽施すれば被罂を過熱したり，不 均一にすることになり，目的に適しない，現 場に於てはメタリコン作淎の後被覆をワイヤ ブラシで摩摖ければ，表面の韦孔さ旨く閉塞 し得ること少知られて居公。

\section{V.メタリコン加工を施した鐵銅の水に依る腐触}

軟銿の丸棒(長さ約 $5.2 \mathrm{~cm}$, 徑 $1.7 \mathrm{~cm}$ ) に 錫·鉛・亞鉛・フルiニウム・フルiニウムー亞
鉛(アルミニウムを施した上に更に亞鉛)・銅・ 真鍮等のメタリコンをワイヤに依る䉓氣式で 


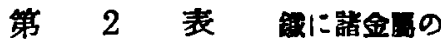

\begin{tabular}{|c|c|c|c|c|c|c|c|c|c|}
\hline \multirow[b]{2}{*}{ 試 驗 片 } & & \multirow[b]{2}{*}{$\begin{array}{l}\text { 長 巳 } \\
(\mathrm{mm})\end{array}$} & \multirow[b]{2}{*}{$\begin{array}{c}\text { 殴 } \\
(\mathrm{mm})\end{array}$} & \multirow[b]{2}{*}{$\begin{array}{l}\text { 表面镍 } \\
\left(\mathrm{cm}^{2}\right)\end{array}$} & \multicolumn{2}{|c|}{ 試驗片の重量（g） } & \multirow[b]{2}{*}{$\begin{array}{c}\text { 差 } \\
W_{2}-W_{1}\end{array}$} & \multirow{2}{*}{ 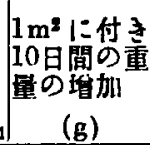 } & \multirow{2}{*}{$\begin{array}{c}\text { 簡浸清挠 } \\
W_{3}\end{array}$} \\
\hline & & & & & $\begin{array}{c}\text { 10日間 } \\
\text { 浸佰胢 } \\
W_{1}\end{array}$ & $\begin{array}{c}\text { 10日間 } \\
\text { 浸演啳 } \\
W_{2}\end{array}$ & & & \\
\hline 1. Fe.Sn & & 52.0 & 16.79 & 31.86 & 86.8989 & 86.5072 & 0.0083 & 2.61 & 86.9200 \\
\hline 2. $\mathrm{Fe}-\mathrm{Sn}$ & 軕出し & 51.5 & 16.64 & 31.27 & 84.8806 & 84.8858 & 0.0052 & 1.66 & 84.8924 \\
\hline 3. Fe-Pb & & 52.5 & 16.97 & 32.52 & 96.1977 & 96.2174 & 0.0197 & 6.06 & 96.2377 \\
\hline 4. $\mathrm{Fe}-\mathrm{Pb}$ & 䒏出し & 51.5 & 16.91 & 31.85 & 94.1615 & $\$ 4.1679$ & 0.0064 & 2.01 & 94.1750 \\
\hline 5. $\mathrm{Fe} \cdot \mathrm{Zn}$ & & 52.0 & 17.08 & 32.48 & 88.7469 & 88.8311 & 0.0842 & 25.94 & - \\
\hline 6. $\mathrm{Fe}-\mathrm{Zn}$ & 䒌出 $C$ & 52.3 & 16.58 & 31.56 & 86.2456 & 86.2616 & 0.0160 & 5.07 & 86.2049 \\
\hline 7. Fe-Al & & 53.0 & 16.69 & 32.17 & 82.5655 & 83.0292 & 0.0637 & 10.80 & 83.0531 \\
\hline 8. $\mathrm{Fe}-\mathrm{Al}$ & 䀠出i & 51.8 & 16.47 & 31.07 & 80.8048 & 80.8484 & 0.0436 & 14.03 & 80.8572 \\
\hline 9. $\mathrm{Fe}-\mathrm{Al} \cdot \mathrm{Zn}$ & & 52.5 & 19.89 & 32.34 & 84.6980 & 84.7668 & 0.0688 & 21.27 & 84.7900 \\
\hline 10. $\mathrm{Fe}-\mathrm{Al}-\mathrm{Zn}$ & 蟿出乙 & 51.5 & 16.86 & 31.74 & 83.934 .3 & 83.9759 & 0.0416 & 12.79 & 84.0083 \\
\hline 11. $\mathrm{Fe}-\mathrm{Cu}$ & & 52.5 & 17.19 & 33.00 & 91.4108 & 91.4420 & 0.0322 & 9.76 & 91.4710 \\
\hline 12. $\mathrm{Fe}-\mathrm{Cu}$ & 跑出し & 52.0 & 16.78 & 31.84 & 88.8846 & 88.9660 & 0.0814 & 25.57 & 89.0006 \\
\hline 13. Fe-Brass & & 52.7 & 16.93 & 32.53 & 89.4365 & 89.4522 & 0.0157 & 4.83 & 89.4715 \\
\hline 14. Fe-Brass & 绝出 $i$ & 53.0 & 16.70 & 32.19 & 88.5601 & 88.5722 & 0.0121 & 3.76 & 88.5978 \\
\hline
\end{tabular}

施した後，各、一つは吹附けたまつ，他の一 つは覆出しを行つたものに就いて水道水に依 る腐蝕試驗を試みた。郎古各表面積の計算, 最初の重量 $W_{1}$ ，或期間水に浸した後取出し て乾燥したものの重量 $W_{2} ， W_{3} \ldots$ 等（水は 其の都度取換へる）を科量し，其の差（ $W_{2}$ -W, $W_{3}-W_{1}$ 等) 加らして試驗片の $1 \mathrm{~m}^{2}$ に付き重量の增加を計算すれば數司に再る 160 日間の試驗に對して第 2 表の結果が得ら れた。第2表から各試驗片の重量の增加と浸 清日數との關係を圖示すれば第9〜10圖が得 られた。次に是等の結果に關して注意した點 記述して見ょう。

第2表及び第9 10圖を見れば各金䐂共喷 射したまつのものよりは嶄出し加工走行つた ものの方が水の作用に依る重量の增加か遙か に少い，又全體を比較し，水の作用の最も少 いるのから列舉すれば $\mathrm{Pb}, \underline{\mathrm{Sn}}, \mathrm{Sn}, \underline{\text { Brass, }}$ Brass, $\mathrm{Pb}, \stackrel{-\mathrm{Al}}{.} \mathrm{Cu}, \underline{\mathrm{Cu}}, \mathrm{Al}, \underline{\mathrm{Al} \cdot \mathrm{Zn}}, \mathrm{Al} \cdot \mathrm{Zn}$,
Zn, Zn の順になって居る．但し脚線は些出 しを意味する. 尤も此の重量の增加の最す少 いものが水に對して耐蝕性か;最も良いとばか りは云はれないこともあらう。それは相當の 程度まて酸化物或は水酸化物の被膜を形成す 第 9 圖

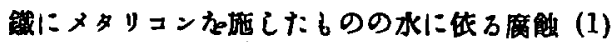
重吾の增加さ日数さの期係

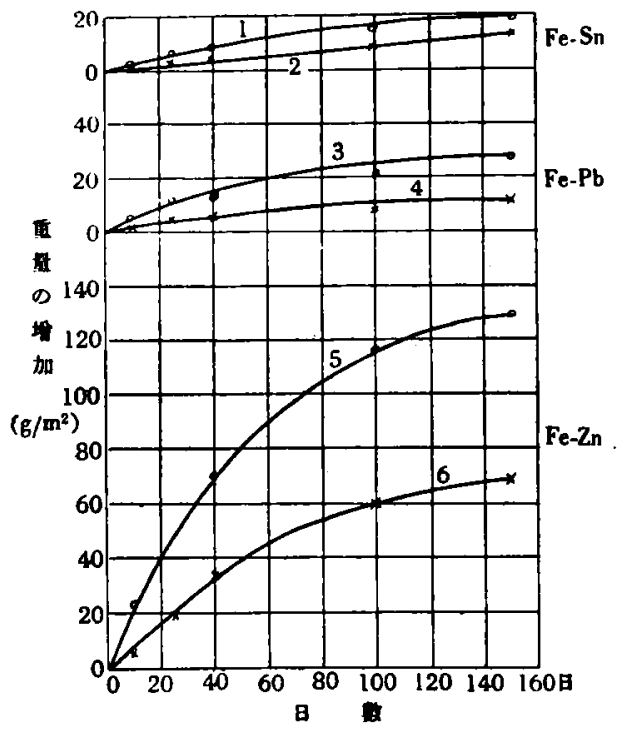


メタリコンわ施したものの水に依る腐蝕

\begin{tabular}{|c|c|c|c|c|c|c|c|c|c|c|}
\hline $\begin{array}{c}\text { 差 } \\
W_{3}-W_{1}\end{array}$ & 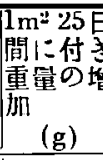 & 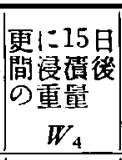 & $\begin{array}{c}\text { 差 } \\
W_{4}-W_{1}\end{array}$ & 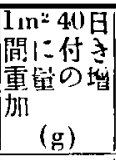 & $\begin{array}{c}\text { 更に60日 } \\
\text { 間浸貢後 } \\
\text { の重曽 } \\
W_{5} \\
\end{array}$ & $\begin{array}{c}\text { 差 } \\
W_{: s}^{r}-W_{1}\end{array}$ & 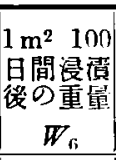 & $\begin{array}{c}\text { 更に50日 } \\
\text { 間浸表後 } \\
\text { の重点 } \\
W_{\mathrm{i}} \\
W_{\mathrm{i}}\end{array}$ & $\begin{array}{c}\text { 差 } \\
W_{6}-W_{1}\end{array}$ & 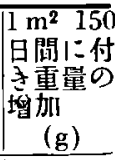 \\
\hline 0.0211 & 6.62 & 80.9298 & 0.0304 & 9.54 & 86.9467 & $0.04 \div 8$ & 15.63 & 86.9589 & 0.0600 & 18.52 \\
\hline 0.0118 & 3.73 & 48.8970 & 0.0164 & 5.15 & 84.9093 & $0.0 \div 87$ & 9.18 & 84.9193 & 0.0390 & 12.47 \\
\hline 0.0400 & 1230 & 96.2448 & 0.0471 & 14.48 & 56.2693 & 0.0716 & 22.02 & 96.2879 & 0.0902 & 27.74 \\
\hline 0.0135 & 4.24 & 94.1788 & 0.0173 & 5.43 & 94.1907 & $0.02 \% 2$ & 9.17 & 94.1988 & 0.0373 & 11.71 \\
\hline- & - & 88.9795 & 0.2326 & 71.61 & 89.1231 & 0.3762 & 115.82 & 89.1649 & 0.4180 & 128.69 \\
\hline 0.0593 & 18.78 & 86.3574 & 0.1118 & 35.42 & $86.4 \Sigma 81$ & 0.1925 & 60.99 & 86.4658 & 0.2202 & 69.96 \\
\hline 0.0876 & 27.23 & 83.0787 & 0.1132 & 35.18 & 83.1133 & 0.1478 & 45.94 & 83.1236 & 0.1581 & 49.15 \\
\hline 0.0524 & 16.87 & 80.8649 & 0.0601 & 19.34 & 80.8844 & 0.0796 & 25.62 & 80.8971 & 0.0923 & 29.71 \\
\hline 0.0920 & 28.48 & 84.8094 & 0.1114 & 34.45 & 84.8640 & 0.1660 & 51.33 & 84.8929 & 0.01949 & 60.27 \\
\hline 0.0740 & 23.31 & 84.0321 & 0.0978 & 30.81 & 84.0768 & 0.1425 & 44.50 & 84.1049 & 0.1706 & 53.74 \\
\hline 0.0602 & 18.24 & 91.4726 & 0.0618 & 18.73 & 91.5133 & 0.1025 & 31.06 & 9].5421 & 0.1313 & 39.79 \\
\hline 0.1160 & 36.43 & 88.9865 & 0.1019 & 32.04 & 89.0194 & 0.1310 & 41.14 & 89.0344 & 0.1498 & 47.05 \\
\hline 0.0350 & 10.76 & 89.4797 & 0.0432 & 13.28 & 89.5002 & 0.05357 & 19.58 & 89.5143 & 0.0778 & 23.92 \\
\hline 0.0377 & 11.71 & 88.5879 & 0.0278 & 8.64 & 88.6111 & 0.0510 & 15.84 & 88.6258 & 0.0657 & 20.41 \\
\hline
\end{tabular}

第 10 圖

鐵にメタリコンネ湤したしのの水に依万腐触 (2) 重望の塯加ミ゙日数ミの關係

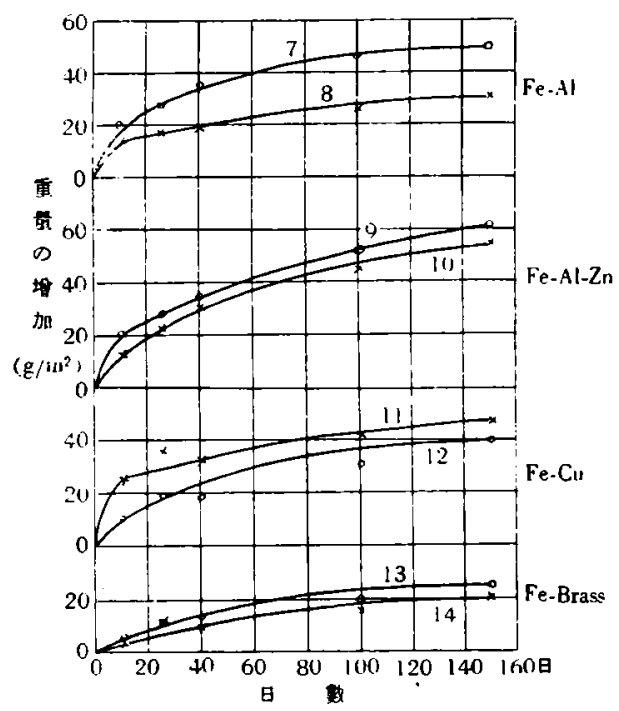

れば其のまつ水の作用の止るものと，何處ま

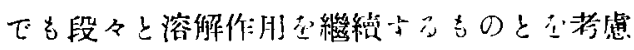
しなけ机ばならふいふらである。

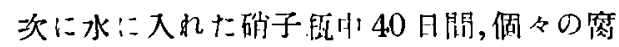

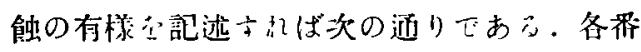

號は試䮑片の順序である。

（1） Fe.Sn, 試䮲片表面灰色にくるる.白 色の反應生成物かふ心はは荆離する。 水澄んで居る。

（2） Fe-Sn，表面が少しく白色の反應生成 物放制離して居る。然し表面の大部分は㱖い て居む。水は祭んて居む。

（3） Fe-Po，表面少暗灰仙:なつて扂る。

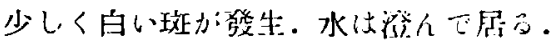

(4) Fe-Pb，同上，但し (3) 51)反應扒少 い栐である。

（5） Fe-Zn，裴面から白い粉末栐の反腐生 成物加制離，沈降し，水は白濁して居る。

（6） Fe- Zn, 表而の處々かく当つて屈るけ

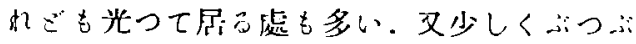

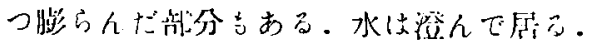

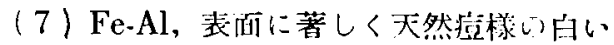
ふつふつしたっの出出來，水底に零䧄狀の

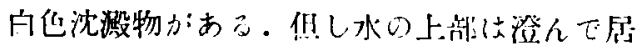


る。

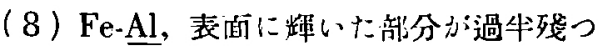
て居る. 然し天然痘様の白いぶつぶつも澤山 出來た。水は澄み，白色沈澱扬抽ない。

（9） Fe-Al-Zn，灰白色の表面に灰照色の 斑點分處々出來て原る。水法滥んで展る。

（10） Fe-Al-Zn，光つた最初の表面と餘り 變つて居ない．然し白い斑點抄多出來て居 る. 水は澄んで居る。

（11） Fe-Cu，表面は暗赤色莫是し，初のま まである.水は澄んで居る。
（12） Fe-Cu，赤く踣出し（少し褐色寺帶び た）された銅のまっで變化は見られない。水 は澄んで居る。

(13） Fe-県鍮，灭綠他䍄消しになつてる表 面に變りはない，水は澄んで居る。

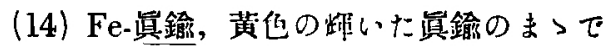

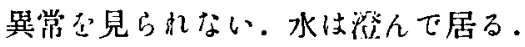

第 11 圆に示した寫真は上述の試驗片を150 日間水道水に浸清した後乾燥したものの外筧 ふ撮影したものである。番號は第 2 表の順序 になつて居る。

第 11 圆鐵に諸金盈のメタリコンが蚛したしのの水に依る腐触
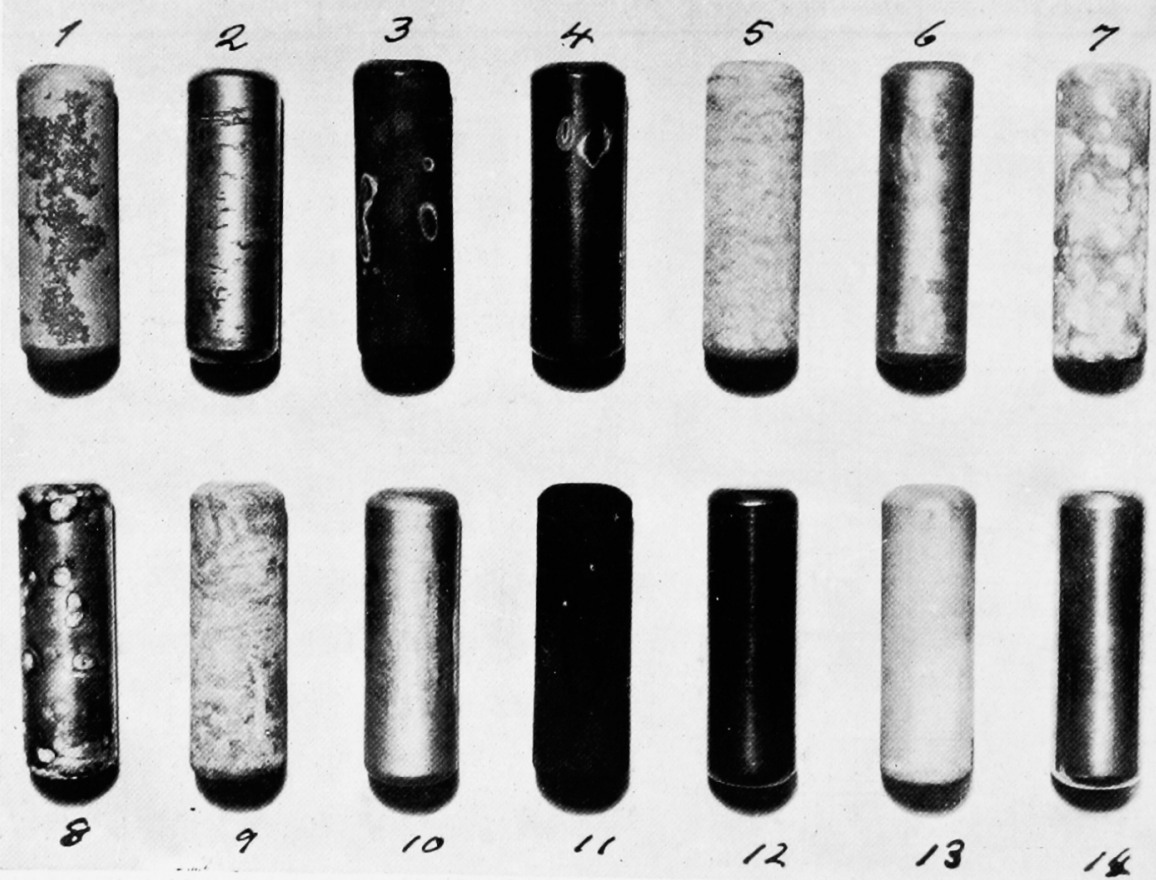

$1 \cdots \mathrm{Fe} \cdot \mathrm{Sn}$

$2 \cdots \mathrm{Fe} \cdot \mathrm{Sn}$

$3 \cdots \mathrm{Fe}-\mathrm{Pb}$

$4 \cdots \mathrm{Fe}-\mathrm{Pb}$

$5 \cdots \mathrm{Fe}-\mathrm{Zn}$

$6 \cdots \mathrm{Fe}-\mathrm{Zn}$

7...Fe-Al

8...Fe-Al

9.. Fe-Al-Zn

$10 \cdots \mathrm{Fe}-\mathrm{Al}-\mathrm{Zn} \quad 11 \cdots \mathrm{Fe}-\mathrm{Cu}$

$12 \cdots \mathrm{Fe}-\mathrm{Cu}$

13..Fe-Brass

14 ...Fe-Brass

\section{VI. メタリコン加エを施したアルミニウムの水に依る腐玲}

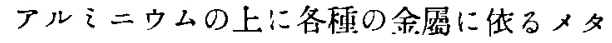
リコン加工さ施した結果は全體の重量から見
て輕いので暗合に依つては重蜜なこともあら

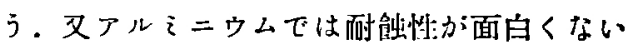


加他金屬さ表面に被覆して防蝕の目的热達 成しょうと企てることにもならう。何れにも せよメタリコン加工が良く出來て貫通した氣 孔等かないならば其の表面のメタリコン加工

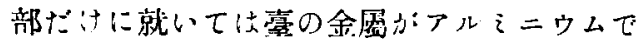
あらうと鐵であらうと變りはないと云ふ結果 它豫想されよう。依つて今回形同大(長之利 $9 \mathrm{~cm}$, 幅䄪 $2.2 \mathrm{~cm}$, 将さ利 $0.2 \mathrm{~cm}$ 位)の瀻板 とアルそニゥム板々そ朋意し，头々 $\mathrm{Sn}, \mathrm{Pb}$, $\mathrm{Zn}, \mathrm{Ag}, \mathrm{Cu}, \overline{\mathrm{Ni}}$ 空䄪 $0.1 \mathrm{~mm}$ づ櫴射した 試驗片造り。例の如く水道水に依る霍触試 驗(5 包で合計 120 日に互る) 遂行した結果 は第 3 表及び第 12 圖:示す通りであつた。

第 12 風

鐵板及びアルミニウム板にメタリコン

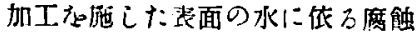
重量の㙕加ミ゙日努ミの關係

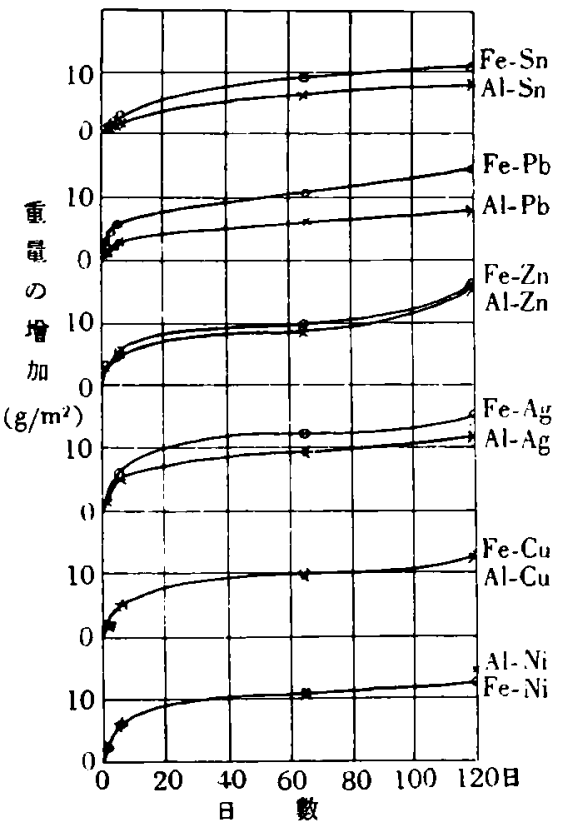

第 12 圆さ見れば鐵板にメタリコン加工さ 施したものの方が同じ金屬をアルミニウム板 に施したちのよりも腐玲に依る重量の堽加が
少量であるが多くなつて居るこのがある。然 しこれは必然的差別あるのてはなく，時間怘 異にして道行されたメタリコン玑工作翡に於

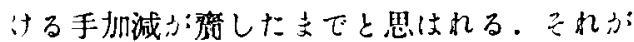
證據には $\mathrm{Cu}$ 及び $\mathrm{Ni} の$ タリコンは效果少 机等しい嘕に脂線ふ:一致し，Zn の場合与大 體同樣である。次に水道水に各試驗片芯 120 日間浸洁したょの(第 3 表の順席)の外覞に就 いて記逊しょう。

（1） Fe-Sn, 試驗片の表面處々に白い水酸 化物か：生成し，j-゙高く出て居る。水底には 少しく沈澱物少ある。但し水は透明である。

(2) Fe- $\mathrm{Pb}$ ，異常ふない.

（3） Fe- $\mathrm{Zn}$ ，表面に白色の水酸化物小;澤山 に生成，水底に气沈澱して居る。

（4） Fe.Ag，上端に赤銹少:少し出て䲩る。

(5) $\mathrm{Fe}-\mathrm{Cu}$ ，一面數䇠所に小突赽栐の憉ら みが發生して居る。他は翼常ふない。

（6） $\mathrm{Fe}-\mathrm{Ni}$ ，少しく白い斑點少出來て居方。

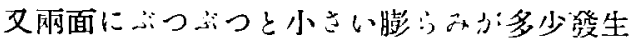
して居る。

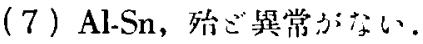

(8) $\mathrm{Al}-\mathrm{Pb}$, 殖ど異常か心い。

（9） Al-Zn，白い水酸化物少:發生し，表洫 にふは心法著いて居る。水底污与白い沈澱少： ある。

（10）Al-Ag，下方に少しく白突狀沈汼小お

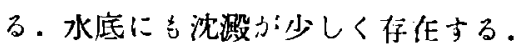

(11) Al-Cu，始ご異常がい。

（12） Al-Ni，表面に多少白い斑點少䋁生， 又細かい天然䖒様の膨らるかかなり澤山に生 成して居る。 


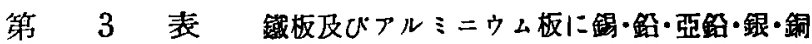

\begin{tabular}{|c|c|c|c|c|c|c|c|c|c|c|}
\hline \multirow[b]{2}{*}{ 金 } & \multirow{2}{*}{ 跖 } & \multicolumn{2}{|c|}{ 試 } & \multicolumn{2}{|c|}{ 片 } & \multirow{2}{*}{$\begin{array}{c}\text { 試驗片の } \\
\text { 最初の重 } \\
\text { 量 } W_{1} \\
(\mathrm{~g})\end{array}$} & \multirow{2}{*}{ 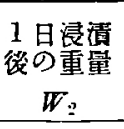 } & \multirow[b]{2}{*}{$\begin{array}{c}\text { 差 } \\
W_{2}-W_{1}\end{array}$} & \multirow{2}{*}{$\begin{array}{c}1 \mathrm{~m}^{2} 1 \text { 旦 } \\
\text { に付 雵 } \\
\text { 量の增加 } \\
(\mathrm{g})\end{array}$} & \multirow{2}{*}{$\begin{array}{c}\text { 更に2日 } \\
\text { 浸責啳の } \\
\text { 重量 } \\
W_{3}\end{array}$} \\
\hline & & $\stackrel{\text { 長 }}{(\mathrm{cm})}$ & $\begin{array}{c}\text { 幅 } \\
(\mathrm{cm})\end{array}$ & $\begin{array}{c}\text { 區 } \\
(\mathrm{cm})\end{array}$ & $\begin{array}{l}\text { 表面皘 } \\
\left(\mathrm{cm}^{2}\right)\end{array}$ & & & & & \\
\hline 1. & $\mathrm{Fe}-\mathrm{Sn}$ & 9.10 & 2.3 & 0.205 & 46.53 & 30.5921 & 30.6020 & 0.0099 & 2.13 & 30.6072 \\
\hline & $\mathrm{Fe}-\mathrm{Pb}$ & 9.05 & 2.3 & 0.229 & 46.83 & 37.2548 & 37.2717 & 0.0169 & 3.61 & 37.2784 \\
\hline & $\mathrm{Fe}-\mathrm{Zn}$ & 9.10 & 2.3 & 0.198 & 45.37 & 29.3218 & 29.3396 & 0.0178 & 3.84 & 29.3468 \\
\hline & $\mathrm{Fe}-\boldsymbol{A g}$ & 9.05 & 2.3 & 0.226 & 46.76 & 33.0832 & 33.0912 & 0.0080 & 1.71 & 33.1059 \\
\hline & $\mathrm{Fe} \cdot \mathrm{Cu}$ & 9.10 & 2.3 & 0.197 & 46.35 & 29.0235 & 29.0348 & 0.0113 & 2.44 & 29.0439 \\
\hline & $\mathrm{Fe}-\mathrm{Ni}$ & 9.10 & 2.3 & 0.193 & 46.26 & 28.0935 & 28.1066 & 0.0131 & 2.83 & 28.1172 \\
\hline & $\mathrm{Al}-\mathrm{Sn}$ & 9.20 & 2.2 & 0.178 & 44.54 & 11.0299 & 11.0381 & 0.0082 & 1.84 & 11.0403 \\
\hline & $\Lambda \mathrm{l}-\mathrm{Pb}$ & 9.20 & 2.2 & 0.190 & 44.81 & 14.5367 & 14.5454 & 0.0087 & 1.94 & 14.5491 \\
\hline & $A \mid-Z n$ & 9.20 & 2.15 & 0.186 & 43.78 & 11.1139 & 11.1290 & 0.0151 & 3.45 & 11.1357 \\
\hline 10. & Al-Ag & 9.20 & 2.2 & 0.193 & 44.88 & 12.8012 & 12.8097 & 0.0085 & 1.89 & 12.8211 \\
\hline 11. & $\Delta l-\mathrm{Cu}$ & 9.20 & 2.2 & 0.183 & 44.65 & 11.5174 & 11.5320 & 0.0146 & 3.27 & 11.5396 \\
\hline 12. & $\mathrm{Al}-\mathrm{Ni}$ & 9.20 & 2.15 & 0.183 & 43.71 & 10.5606 & 10.5756 & 0.0150 & 3.43 & 10.5835 \\
\hline
\end{tabular}

第 13 㘣 アルミニウムに諸金屬のメタリコンわ地したものの鹰蝕試驗

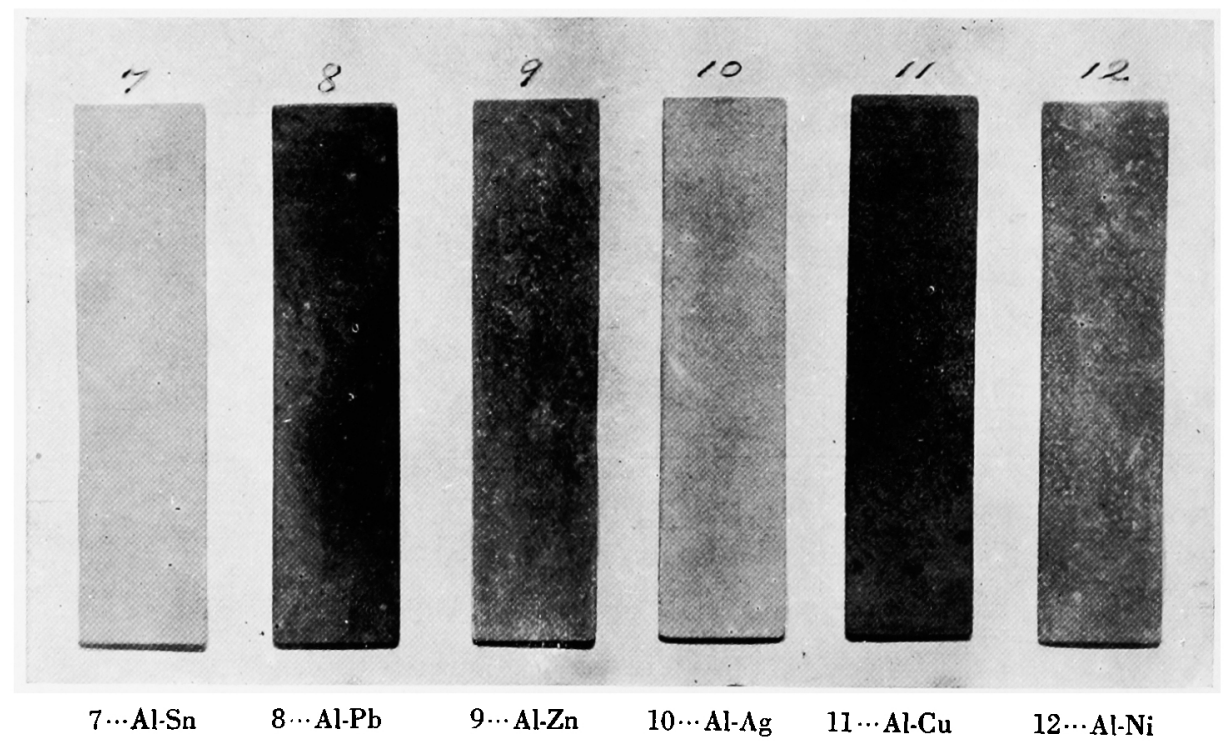

第 13 圖の寫眞は上述の試駘片小 No. 7〜 12，郎ちアルネニウム各辜にしたものの 120 日後に水から取り出したときの外觀き示す。

双, アルiニウムの防蝕法としてアルマイ トか優秀な地位を占めて居るか，もつと手輕 に相當の效果き與へる方法もある。例へば重 クロム酸㧈里のアルカリ溶液と共にアルi二

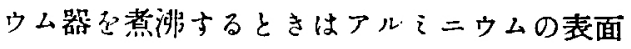
に一見アルマイトに似た溜澤の感あるものを 與へる、乙はBauer-Vogel 法である. 今此の 處理走行つた媵更に適當の金屬老以てメタリ コン加工を施すことは筫际闆題としてかなり 有效なものではなからうかと云ふことにな る、そこで筆者はアルぇニウムの試驗片の上 


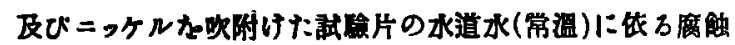

\begin{tabular}{|c|c|c|c|c|c|c|c|c|c|c|}
\hline $\begin{array}{c}\text { 差 } \\
W_{3}-W_{1}\end{array}$ & 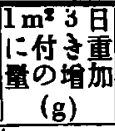 & 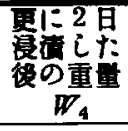 & $W_{4}-\left.W_{1}\right|^{1}$ & 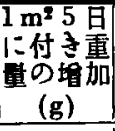 & 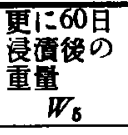 & $\begin{array}{c}\text { 差 } \\
W_{5}-W_{1}\end{array}$ & 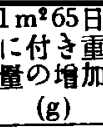 & 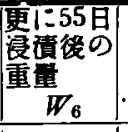 & $\begin{array}{c}\text { 差 } \\
W_{6}-W \\
\end{array}$ & $\begin{array}{l}\text { 星に付 } \\
\text { 重量の增 } \\
\text { 加 (g) }\end{array}$ \\
\hline 0.0151 & 3.25 & 30.6101 & 0.0180 & 3.87 & 30.6337 & 0.0416 & 8.94 & 30.6428 & 0.0507 & 10.50 \\
\hline 0.0236 & 5.04 & 37.2818 & 0.0270 & 5.77 & 37.3051 & 0.0503 & 10.75 & 37.3236 & 0.0684 & 14.60 \\
\hline 0.0250 & 5.39 & 29.3494 & 0.0276 & 5.95 & 29.3670 & 0452 & 9.75 & 29.3976 & 0.0758 & 16.35 \\
\hline 0.0227 & 4.85 & 33.1139 & 0.0307 & 6.57 & 33.1408 & 0.0576 & 12.32 & 33.1547 & 0.0715 & 15.29 \\
\hline 0.0204 & 4.40 & 29.0486 & 0.0251 & 5.42 & 29.0709 & 0.0474 & 10.23 & 29.0828 & 0.0593 & 12.79 \\
\hline 0.0237 & 5.12 & 28.1224 & 0.0289 & 6.25 & 28.1425 & 0.0490 & 10.59 & 28.1534 & 0.0599 & 12.95 \\
\hline 0.0104 & 2.33 & 11.0422 & 0.0123 & 2.76 & 11.0574 & 0.0275 & 6.17 & 11.0660 & 0.0361 & 8.11 \\
\hline 0.0124 & 2.77 & 14.5521 & 0.0154 & 3.44 & 14.5685 & 0.0318 & 6.99 & 14.5804 & 0.0437 & 9.75 \\
\hline 0.0218 & 4.98 & 11.1363 & 0.0224 & 5.12 & 11.1560 & 0.0421 & 9.62 & 11.1857 & 0.0678 & 15.49 \\
\hline 0.0199 & 4.43 & 12.8279 & 0.0267 & 5.95 & 12.8438 & 0.0426 & 9.49 & 12.8561 & 0.0549 & 12.23 \\
\hline 0.0222 & 4.97 & 11.5442 & 0.0268 & 6.00 & 11.5636 & 0.0462 & 10.35 & 11.5729 & 0.0555 & 12.43 \\
\hline 0.0229 & 5.24 & 10.5880 & 0.0274 & 6.27 & 10.6099 & 0.0493 & 11.28 & 10.6233 & 0.0627 & 14.34 \\
\hline
\end{tabular}

に Bauer-Vogel 法を施し，更に其の上に錫 メタリコン(䶚出し)等を施したものを試して 見ると如何にも具合が宜しい，依つて及次の 樣な問題すおる。

フルミニウムを鑄造し易くする爲に亞鉛及 は銅を加へたものを使用する。ナルぇニウム 鑄物て温沸しを造り，それに內外共漆を燒附 け，外面には特に鐵銹を叙布して鐵瓶㥞の外 觀を與へた工蒘品が市場に出て居る。これ は山形市の伊藤嘉平治氏が發明し，特許を受 け，大阪市の池田フルiで製造さ引受け，商 品名を萬代瓶と云はれて居るすのである．然 るに萬代㼛はフルネニウムに亞鉛を含む爲に
內面の涂の氣孔から白い酸化亞鉛か吹出すこ

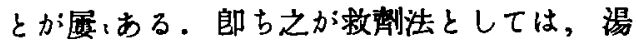
沸しの內部に Bauer-Vogel 法を施し，次に 錫メタリコン(艶出し)加工を施し得れば中し 分のない品となる譯である。无も此の處理は

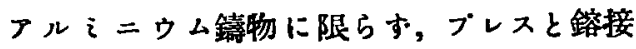
で造つた普通の製品にも施さるべて，外面 は敢へてアルナイトに依らなくとすアルるこ ウムが左樣に腐蝕することのないのに，內面 は水と絕えす接觸して非常に荒廢する點に鑑 み，斯梯な處理支利用したらどうかと思次 第である(此の加工法はビストルの筒口を改 良して不日實現される筈である)。

\section{VII. メタリコン加工を施したマグネシウムに依る腐神}

普通の狀態に於てアルぇニゥムは水道水に 數日間浸漬したからと云つて著しく简蝕又は 溶解する等のことはないが，、グネシウムに 至つてはそれが顯著で如何に應蝕の甚だしい ののであるかが首肯される，從つてマグネシ
ウムに直接各種金屬のノタリコン加工を施す 場合には被膜の內外に連續した氣孔は絕對に 禁物と云はねばならない. 今長さ約 $8 \mathrm{~cm}$, 徑 䄪 $0.7 \mathrm{~cm}$ の純マグネシウムの丸棒尼用意し, 其の表面に例の如く約 $0.1 \mathrm{~mm} た ゙ け \mathrm{Sn}, \mathrm{Pb}$, 
第 4 表 マダネシウムに諸金娄のメタリコンが

\begin{tabular}{|c|c|c|c|c|c|c|c|}
\hline 試 驗 片 & & $\begin{array}{l}\text { E } \\
(\mathrm{cm}) \\
\end{array}$ & $\begin{array}{c}\begin{array}{c}\text { 彺 } \\
(\mathrm{cm})\end{array} \\
\end{array}$ & $\begin{array}{l}\text { 表面楀 } \\
\left(\mathrm{cm}^{2}\right)\end{array}$ & 腐蝕液 & 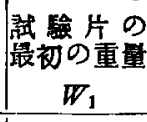 & 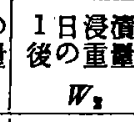 \\
\hline 1. $\mathrm{Mg} \cdot \mathrm{Sn}$ & & 7.95 & 0.672 & 206.95 & 水道水 & 5.9801 & (อ 5.9822 \\
\hline 2. $\mathrm{Mg}-\mathrm{Sn}$ & & 8.00 & 0.685 & 209.67 & $3 \% \mathrm{NaCl}$ & 6.3431 & $x$ \\
\hline 3. $\mathrm{Mg}-\mathrm{Pb}$ & & 8.10 & 0.686 & 214.85 & 水道水 & 7.7518 & (ㄱ) 7.7553 \\
\hline 4. $\mathrm{Mg}-\mathrm{Pb}$ & & 7.90 & 0.700 & 204.75 & $3 \% \mathrm{NaCl}$ & 8.4608 & $x$ \\
\hline 5. $\mathrm{Mg} \cdot \mathrm{Zn}$ & & 8.05 & 0.697 & 212.40 & 水道水 & 6.9508 & (ㅇ) 6.9599 \\
\hline 6. $\mathrm{Mg}-\mathrm{Zn}$ & & 8.00 & 0.685 & 209.67 & $3 \% \mathrm{NaCl}$ & 6.5663 & $x$ \\
\hline 7. $\mathrm{Mg}-\mathrm{Zn}$ & 野出 $i$ & 8.10 & 0.718 & 215.26 & 水道水 & 8.5326 & ○ 8.5350 \\
\hline 8. $\mathrm{Mg}-\mathrm{Zn}$ & 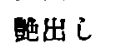 & 8.05 & 0.715 & 212.62 & $3 \% \mathrm{NaCl}$ & 9.0471 & (ㅇ 9.0530 \\
\hline 9. $\mathrm{Mg}-\mathrm{Al}$ & & 8.00 & 0.674 & 209.53 & 水道水 & 5.0352 & (C) 5.0385 \\
\hline 10. $\mathrm{Mg}-\mathrm{Al}$ & & 8.05 & 0.678 & & $3 \% \mathrm{NaCl}$ & 5.4067 & $x$ \\
\hline 11. $\mathrm{Mg}-\mathrm{Ag}$ & & 8.05 & 0.690 & & 水道水 & 7.9022 & $x$ \\
\hline 12. $\mathrm{Mg} \cdot \mathrm{Ag}$ & & 8.10 & 0.708 & & $3 \% \mathrm{NaCl}$ & 8.2428 & $x$ \\
\hline 13. $\mathrm{Mg} \cdot \mathrm{Cu}$ & & 8.05 & 0.693 & 212.35 & 水道水 & 7.0078 & 7.0147 \\
\hline 14. $\mathrm{Mg} \cdot \mathrm{Cu}$ & & 8.05 & 0.694 & & $3 \% \mathrm{NaCl}$ & 6.3641 & $x$ \\
\hline 15. $\mathrm{Mg}-\mathrm{Ni}$ & - & 7.90 & 0.674 & & 水道水 & 5.7031 & $x$ \\
\hline 16. $\mathrm{Mg} \cdot \mathrm{Ni}$ & & 8.00 & 0.676 & & $3 \% \mathrm{NaCl}$ & 6.1446 & $x$ \\
\hline 17. $\mathrm{Mg}$-Brass & & 8.00 & 0.696 & & 水道水 & 6.6529 & $x$ \\
\hline 18. Mg-Brass & & 8.05 & 0.705 & & $3 \% \mathrm{NaCl}$ & 7.4687 & $x$ \\
\hline 19. Mg-Brass & 蠤出し & 8.00 & 0.720 & 210.11 & 水道水 & 8.2523 & (อ) 8.2580 \\
\hline 20. Mg-Brass & 㬐出 & 8.05 & 0.735 & & $3 \% \mathrm{NaCl}$ & 9.8369 & $x$ \\
\hline
\end{tabular}

$\mathrm{Zn}, \mathrm{Al}, \mathrm{Ag}, \mathrm{Cu}, \mathrm{Ni}$, 真銩 (Brass) の各金屬 のメタリコンを施し（或すのは橡出しを行 ふ），それ等に就いて約 $300 \mathrm{cc}$ の水道水及び $3 \%$ 食監水に依る腐蝕試驗を行へば第 4 表に 示す結果が得られた。第4表中の印を附けた 處までは試驗片が元狀或は良好の狀態である が，○となれば少しく缺陷を生じ，又は全然 被膜が制離して不良狀態に陷つたこと示

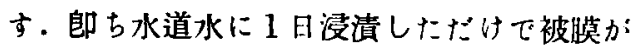
剥離崩壤さ來したものは $\mathrm{Ag}, \mathrm{Ni}$, 面鍮で, 是 等は電化列中 $\mathrm{Mg}$ に對してすつと贵金屬側 にある金屬自身或は金屬を含むすのでる。 及3\%食監水に1 日浸漬しただけて崩壤した ものは $\mathrm{Sn}, \mathrm{Pb}, \mathrm{Zn}, \mathrm{Al}, \mathrm{Ag}, \mathrm{Cu}, \mathrm{Ni}$, 頁鍮 (噴射の去つ及び梪出し)である。つまり食䜿
水には微細な氣孔も到底許容されないことを 示す。鬼に角 3 回に孟り液を取換へて 5 日間 の浸清に耐へて完全と見做されたすのは水道 水に對し $\tau \mathrm{Pb}, \mathrm{Zn}, \mathrm{Zn}$ (艶出し)，同しく 稍、宜しいものは $\mathrm{Sn}, \mathrm{Al}$ ，貝鍮 (艶出し)等で，

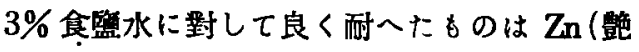
出し)のみであつた。

第 14 圆の舄真は $3 \%$ 食嫄水に1 日浸清し て被膜剩離崩壤を來した各試驗片の外䧽を示 す. 又第 15 圖は上述の如くマグネシウムに諸 金䖲のメタリコンを施した後腐蝕試驗を行つ た各試驗片の外観を示す（第 4 表と對照のこ と）、第 15 圖中上段は成績優，中段は良，下 段は不良ですつた。

及第 15 圖中上段及び中段の試驗片は 5 日 
施したるのの水道水及び $3 \%$ 食監水に体万腐蝕

\begin{tabular}{|c|c|c|c|c|c|c|c|}
\hline $\begin{array}{c}\text { 差 } \\
W_{2}-W_{1} \\
\end{array}$ & 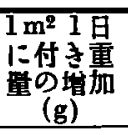 & 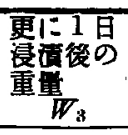 & $\begin{array}{c}\text { 差 } \\
W_{:}-W_{1}\end{array}$ & $\begin{array}{c}1 \mathrm{~m}^{2} 2 \text { 日 } \\
\text { に付莌重 } \\
\text { 量の增加 } \\
(\mathrm{g})\end{array}$ & $\begin{array}{c}\text { 更にs旦 } \\
\text { 浸㣱後の } \\
\text { 董量 } \\
W_{4} \\
\end{array}$ & $\begin{array}{c}\text { 差 } \\
W_{4}-W_{1} \\
\end{array}$ & 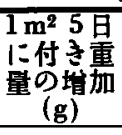 \\
\hline 0.0021 & 0.10 & $O^{5.9813}$ & 0.0312 & 0.06 & $\times 5.9543$ & & \\
\hline 0.0035 & 0.16 & (อ) 7.7559 & 0.0041 & 0.19 & () 7.7569 & 0.0051 & 0.24 \\
\hline 0.0091 & 0.43 & (O) 6.9602 & 0.0094 & 0.44 & () 6.9600 & 0.0092 & 0.43 \\
\hline 0.0024 & 0.11 & (-) 8.5360 & 0.0034 & 0.16 & () 8.5390 & 0.0064 & 0.30 \\
\hline 0.0059 & 0.28 & () 9.0530 & 0.0059 & 0.28 & () 9.0542 & 0.0071 & 0.33 \\
\hline 0.0033 & 0.16 & (a) 5.0431 & 0.0079 & 0.38 & $\times 5.0412$ & & \\
\hline 0.0069 & 0.32 & & & & & & \\
\hline 0.0056 & 0.27 & 8.2624 & 0.0100 & 0.48 & $\times 8.2754$ & & \\
\hline
\end{tabular}

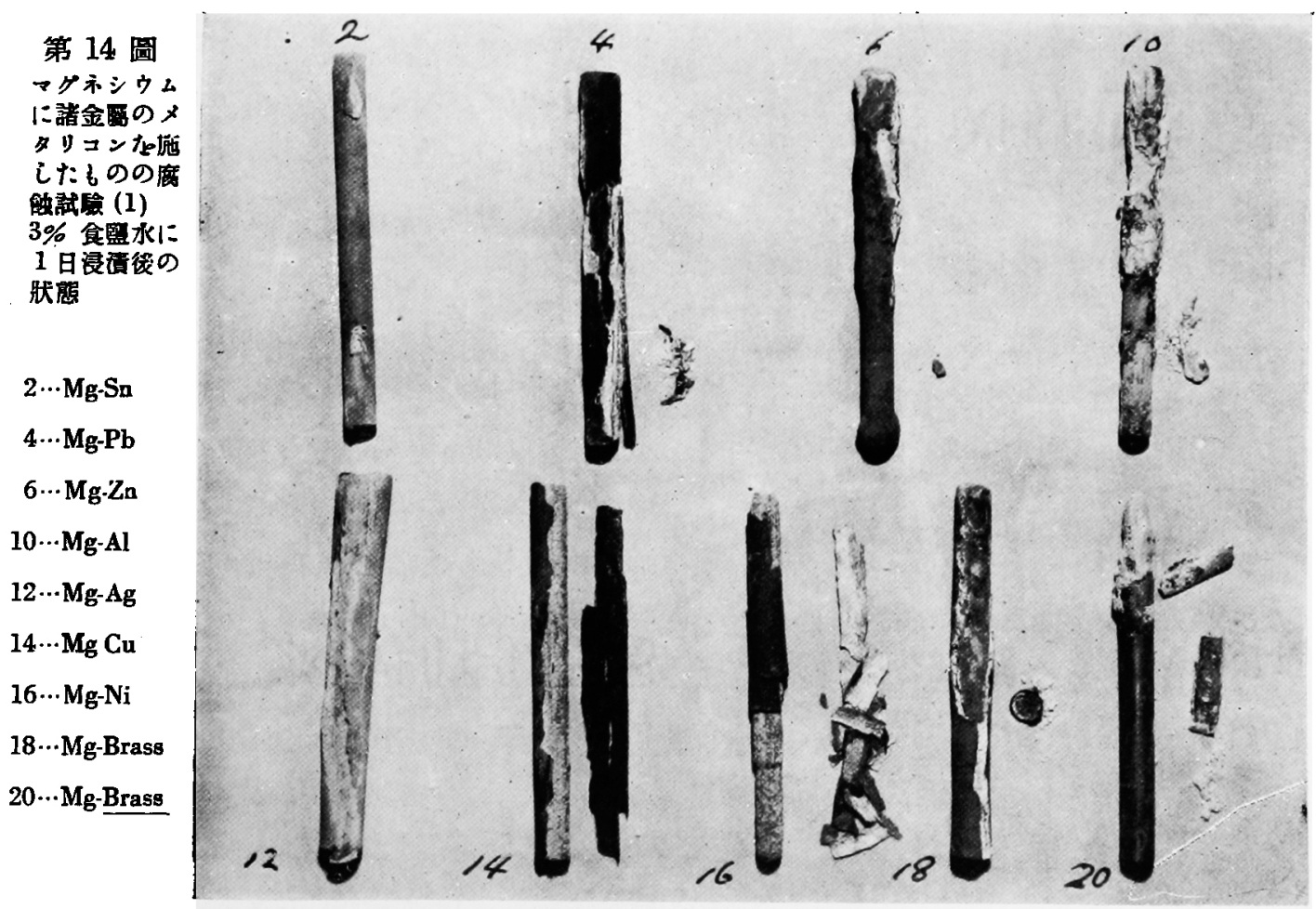


第 15 圖

マグネシウムに諸金屚のメタリコン

か施したものの腐蝕試驗 (2)

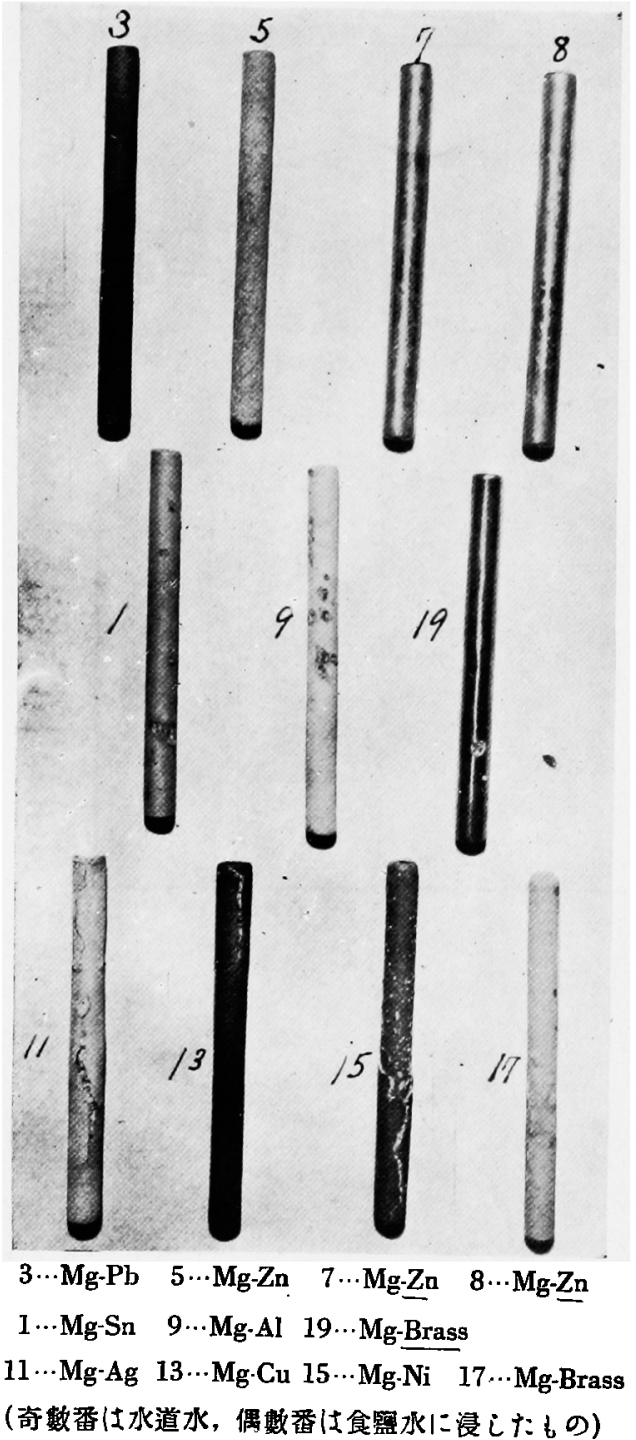

間液に浸したものであるか，其の 5 日後の液 及び試驗片の外觀施記述すれば次の通りであ る(番號は試驗片と同様)。

(1) Mg-Sn, 試驗片の表面上 5〜6䉪所に 破れがある。水底に少し白色沈澱を見る。但
し水は透明。

(3) $\mathrm{Mg}-\mathrm{Pb}$ ，異常がない。

（5） Mg-Zn，表面に白い綿の樣な水酸化物 が澤山附着して居る. 水は白濁.

（7） Mg-Zn, 試驗片の下部が少しく黑す んだが他は大體輝いたまつになつて居る．水 は透明。

（8） Mg-Zn, 試驗片の表面立びに器底に 白い水酸化物丸゙沈積して居る．水も稍、白濁.

（9） Mg-Al，表面の處々に小さい破れ堹 した. 水底に少し白色沈澱がある.水は透明.

(19） $\mathrm{Mg}$-真鍮，表面の 1 箇所に小さい破れ を生じた。他は踔いたまつになつて居る。水 は透明.

双，マグネシウムの上に值にメタリコン加 工を施したすのに就いては上述の通りである が,マグネシウムの試驗片に對してザッボンエ ナィル或はコールタールを完全に塗附する か, 刃は重クロム酸加里のアルカリ溶液と共 に惹沸して酸化被膜を與へる等の處理を行へ ば定䀭水に對しても或程度或は相當に耐創性 を得ることになる。然しザッボンエナィル或 はコールタールの様な有機物の上には今の所 作菜の經驗上メタリコンが旨く行はれないか ら後の方の Bauer-Vogel 法に依る酸化被膜 を施した上に(或は亞セレン酸法に依るの 面白からう)メタリコンを施せば臺がアルミ ニウムの場合と同樣に相賞のものが得られる ことを經驗し得たのであるが，其の結果は大 體アルミニウムの場合と同梯の観があるか ら，此處にはそれを省略することにする。 


\section{VIII. 結}

論

メタリコンに依る防触法としては其の被膜 被膜か:完全である間は喜の金屬か何であらう の気孔か:臺の金屬まで貫通して居ないことか： と同㥞の而蝕性: 名期街さるべきである。併し 畈要である。多孔性て避するにはワイヤブ 乍ら輕金屬及び其の合金に對しては管万表面 ラシ等沪依る晒出しは宜しい。時には熱處理

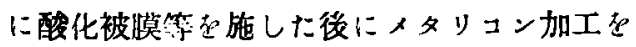
に体って之遂行することも出來よう。結局行つた方か無嚾であることが知られた。(完) (1937 年 12 月) 